\title{
Cortical Blindness
}

National Cancer Institute

\section{Source}

National Cancer Institute. Cortical Blindness. NCI Thesaurus. Code C118707.

Visual impairment due to visual cortex dysfunction. 